\title{
Kebijakan Pemerintah Daerah Dalam Pengembangan Pariwisata Kawasan Rawan Bencana di Desa Ban, Kabupaten Karangasem, Bali
}

\author{
Putri Kusuma Sanjiwani*, Luh Putu Kerti Pujani \\ Universitas Udayana \\ *kusumasanjiwani@unud.ac.id
}

\begin{abstract}
Karangasem Regency has Mount Agung which is included in one of the active volcano clusters in Indonesia, so it has a significant disaster risk if it used as a tourist attraction. Desa Ban is one of the villages within the radius of the Gunung Agung Disaster Prone Area. Desa Ban must get different treatment if it is developed as a tourist attraction. This research was conducted to determine the form of Local Government policies in the development of tourism in the Volcano Disaster Prone Areas in Ban Village, Karangasem Regency. The research method in this study uses the empirical legal method in studying and looking at the law in terms of tourism. Analyze the problem based on authority theory, functional theory, policy concepts, agrotourism concepts and decentralization principle. Using legal analysis techniques and legal evaluation in Local Government policy making. The results of this study are the policy of developing agrotourism as an ideal tourism business that can be carried out in the volcano prone areas. This policy is related to the limitation of tourism activities to reduce the risk of volcano natural disasters so that the loss of the community or minimizing disaster victims can be reduced if the eruption occurs in an unexpected time.
\end{abstract}

Keywords: Agro-Touris; Tourism Polic; Disaster-Prone Areas

\begin{abstract}
ABSTRAK
Kabupaten Karangasem memiliki Gunung Agung yang termasuk dalam salah satu cluster gunung berapi aktif di Indonesia, sehingga memiliki risiko bencana yang signifikan jika digunakan sebagai objek wisata. Desa Ban adalah salah satu desa dalam radius Daerah Rawan Bencana Gunung Agung. Desa Ban harus mendapat perlakuan berbeda jika dikembangkan sebagai objek wisata. Penelitian ini dilakukan untuk mengetahui bentuk kebijakan Pemerintah Daerah dalam pengembangan pariwisata di Daerah Rawan Bencana Gunung Berapi di Desa Ban, Kabupaten Karangasem. Metode penelitian dalam studi menggunakan metode hukum empiris dalam mempelajari dan melihat hukum dalam hal pariwisata. Analisis masalah dilakukan berdasarkan teori otoritas, teori fungsional, konsep kebijakan, konsep agrowisata dan prinsip desentralisasi. Teknik analisis hukum dan evaluasi hukum digunakan dalam pembuatan kebijakan Pemerintah Daerah. Hasil dari penelitian ini adalah kebijakan pengembangan agrowisata sebagai bisnis pariwisata yang ideal yang dapat dilakukan di daerah rawan gunung berapi. Kebijakan ini terkait dengan pembatasan kegiatan pariwisata untuk mengurangi risiko bencana alam gunung berapi sehingga kehilangan masyarakat atau meminimalkan korban bencana dapat dikurangi jika letusan terjadi dalam waktu yang tidak terduga.
\end{abstract}

Kata Kunci: Agro-Touris; Tourism Polic; Disaster-Prone Areas 


\section{PENDAHULUAN}

Pengembangan pariwisata menjadi bagian urusan rumah tangga masingmasing daerah di Indonesia sesuai dengan arahan ketetapan Peraturan Pemerintah Nomor 38 Tahun 2007. Pemerintah Daerah Kabupaten atau Kota memegang porsi paling besar dalam pembagian kewenangan terhadap pengembangan pariwisata. Pengembangan pariwisata Kabupaten Karangasem melibatkan tiga komponen penting yang berperan aktif yaitu masyarakat lokal, pemerintah dan pengusaha pariwisata.Pengembangan pariwisata di Kawasan Rawan Bencana Gunung Api nampak tidak asing di wilayah Indonesia. Gunung Api di wilayah Indonesia memiliki pesona eksotis sehingga banyak diantara gunung tersebut menjadi daya tarik wisata alam seperti Gunung Tangkuban Perahu di Provinsi Jawa Barat, Gunung Bromo di Provinsi Jawa Timur, dan Gunung Agung di Provinsi Bali.

Keindahan daya tarik wisata alam dapat berubah menjadi menyeramkan apabila terjadi peningkatan aktifitas dan memuncak sampai pada erupsi. Erupsi besar Gunung Agung terjadi pada tahun 1963 dan pada bulan September 2017 mengalami perubahan aktifitas menuju tanda-tanda erupsi. Gunung Agung mulai menunjukkan perubahan dari status waspada menjadi status siaga, tepat pada bulan November 2017 peningkatan status siaga memasuki status awas (level IV) yang menjadi status tertinggi sebuah gunung api yang wajib untuk diwaspadai. Status awas pada gunung api memiliki potensi erupsi yang tidak dapat diprediksi dengan jangkauan letusan yang tidak dapat diprediksi. Tahun 2018, riwayat Gunung Agung beberapa kali mengalami erupsi dengan ketinggian kolom asap mencapai 2,5 km pada bulan Januari. Pemerintah Daerah Kabupaten Karangasem memetakan Kawasan Rawan Bencana Gunung Api untuk menekan resiko bencana erupsi Gunung Agung.
Perubahan status awas dan erupsi Gunung Agung juga sangat berpengaruh terhadap kestabilan pariwisata Provinsi Bali pada umumnya dan pariwisata Kabupaten Karangasem pada khususnya. Bandara Internasional I Gusti Ngurah Rai mengalami buka-tutup bandara sehingga banyak wisatawan yang tidak dapat melakukan kegiatan berwisata ke Bali maupun kembali ke negaranya. Terlalu masif berita-berita di media sosial maupun berita-berita baik cetak maupun elektronik mengakibatkan citra pariwisata Bali menjadi semakin memburuk.

Desa Ban merupakan sebuah desa yang berada di Kecamatan Kubu, termasuk dalam zona Kawasan Rawan Bencana Gunung Api. Desa Ban berada pada zona merah yaitu pada zona Kawasan Rawan Bencana II yang berpotensi mengalami dampak erupsi yang cukup parah. Desa Ban merupakan kawasan strategis pariwisata di Kabupaten Karangasem yang membutuhkan perencanaan tata ruang yang spesifik sehingga pengembangan pariwisata Desa Ban tidak boleh dilakukan secara sembarangan.

Pariwisata merupakan salah satu aset Kabupaten Karangasem untuk menopang Pendapatan Asli Daerah (PAD) baik dari pajak daerah maupun retribusi.Pilihan terbaik dalam mengembangkan pariwisata di Kawasan Rawan Bencana adalah mengembangkan pariwisata berupa agrowisata (daya tarik wisata buatan).Kawasan Rawan Bencana hendaknya bukanlah kawasan yang layak digunakan sebagai pemukiman.

\section{TINJAUAN PUSTAKA}

Kewenangan (authority, gezag) adalah kekuasaan yang diformalkan baik terhadap segolongan orang tertentu, maupun kekuasaan terhadap suatu bidang pemerintahan secara bulat yang berasa, dari kekuasaan legislatif maupun dari kekuasaan pemerintah (Marbun, 1997). Teori kewenangan akan menganalisis tentang batasan kewenangan Pemerintah 
Daerah Kabupaten Karangasem dalam mengurus rumah tangga daerah pada sektor pariwisata.

Kebijakan adalah sebagai pilihan pemerintah untuk melakukan atau tidak melakukan sesuatu (whatever governments choose to do or not to do) (Winarno, 2002). Pemerintah Daerah Kabupaten Karangasem mengambil kebijakan pariwisata untuk mengatasi dampak erupsi Gunung Agung yang berimplikasi negatif dalam sektor pariwisata.

Desentralisasi dapat berpatokan melalui Pasal 18 Undang-Undang Dasar (UUD) 1945 dan perubahannya dimana dalam pasal ini diletakkan dasar konstitusional tentang hubungan antara pusat dan daerah, yaitu pada pasal 18 ayat 2 menyatakan bahwa daerah mengatur dan mengurus sendiri urusan pemerintahan menurut asas otonomi dan tugas pembantuan.

\section{METODE PENELITIAN}

Penelitian ini merupakan penelitian hukum empiris,suatu metode penelitian hukum yang berfungsi untuk melihat hukum dalam artian nyata dan meneliti bagaimana bekerjanya hukum di lingkungan masyarakat. Sumber-sumber hukum penelitian ini adalah bahan hukum primer dan bahan hukum sekunder.Teknik pengumpulan data menggunakan teknik observasi, wawancara dan dokumentasi.Teknik analisis bahan hukum menggunakan teknik analisis dan teknik evaluasi.

\section{HASIL DAN PEMBAHASAN}

Pada 2015, Asia-Pasifik menjadi wilayah paling rawan bencana di dunia. 160 bencana dilaporkan di kawasan tersebut, mencakup 47 persen dari 344 bencana dunia (ESCAP United Nation, 2015). Bencana gunung api merupakan salah satu dalam bencana alam tersebut. Lingkaran cincin api di wilayah selatan Indonesia tidak mengenyampingkan pulau Bali sebagai salah satu pulau di dalam lingkaran tersebut. Gunung Agung di Kabupaten Karangasem merupakan bagian sisi selatan Indonesia dari jajaran lingkaran cincin api Indonesia.

Erupsi Gunung Agung telah membuat keadaan pariwisata Bali menjadi tidak stabil. Masifnya pemberitaan media cetak dan elektronik internasional maupun lokal telah menggiring citra pariwisata Bali menjadi citra negatif. Wisatawan mulai membatalkan kunjungan wisata bahkan ada yang menyudahi liburan mereka di Bali dan kembali ke negara asal wisatawan.

Erupsi Gunung Agung juga berpengaruh besar pada pergerakan roda ekonomi pengusaha pariwisata dan masyarakat lokal seperti berikut :

1. Para pengusaha pariwisata mulai mengurangi jumlah karyawan mereka dengan memberlakukan PHK (Pemutusan Hubungan Kerja) secara sepihak.

2. Pengusaha pariwisata mengurangi waktu operasional usaha pariwisata seperti pada umumnya usaha pariwisata beroperasi 7 hari seminggu menjadi 5 hari dalam seminggu.

3. Pengusaha pariwisata memberlakukan pemotongan insentifpelayanan untuk tenaga kerja pada kisaran $50 \%-70 \%$ dari insentif yang biasa diterima.

4. Pengusaha pariwisata memberlakukan pemotongan upah atau gaji tenaga kerja baik tenaga kerja tetap maupun daily worker sampai pada kisaran maksimum 50\% dari upah atau gaji yang seharusnya diterima.

\section{Gambaran Umum Desa Ban}

Desa Ban terletak di Kecamatan Kubu, Kabupaten Karangasem dengan luas wilayah Desa Ban adalah seluas 7.095 ha. Luas keseluruhan wilayah Desa Ban terbagi atas wilayah permukiman seluas 106,446 ha dan wilayah perkebunan rakyat seluas $6.962,85$ h. Batas-batas wilayah Desa Ban, yakni :
a. Utara
: Desa Tianyar
b. Timur
: Desa Sukadana
c. Selatan
: Hutan Lindung
d. Barat
: Desa Tianyar Tengah 
Desa Ban tergolong desa yang berada di daerah pegunungan yang memiliki curah hujan $2.138 \mathrm{~mm}$ dan ketinggian $500 \mathrm{mdpl}$.

Desa Ban yang letaknya terpencil dan jauh dari perkotaan menyebabkan tidak adanya aktifitas pariwisata sehingga belum tersedianya infrastruktur pariwisata.Desa Ban bertitik fokus dalam kegiatan perkebunan dan sebagian besar kehidupan masyarakat bertumpu pada perkebunan. Berdasarkan potensi varietas tanaman, Desa Ban merupakan penghasil mete kualitas terbaik di Bali.

\section{Potensi Desa Ban sebagai Daya Tarik Wisata}

Kebijakan Pemerintah Daerah dalam pengembangan pariwisata di Desa Ban harus mempertimbangkan lokasi, potensi dan dampak erupsi gunung api. Desa Ban memiliki potensi besar di sektor perkebunan. Perkebunan kacang mete di Desa Ban juga dilirik oleh investor asing. Desa Ban dapat menghasilkan jumlah kacang mete sekitar \pm 3500 ton pertahun. Memiliki siklus panen kacang mete pada bulan Juli - Agustus.Kebiasaan masyarakat lokal Desa Ban adalah menjual hasil panen kacang mete sebagai bahan baku, bukan olahan setengah jati maupun produk jadi.

Kacang mete yang sudah dipanen langsung dijual kepada pengepul tanpa proses pengolahan. Masyakat lokal Desa Ban masih minim pengetahuan dalam mengolah kacang mete sehingga penghasilan masyarakat lokal masih kurang. Kacang mete tersebut selanjutnya akan dibeli oleh pengepul secara gelondongan yang akan dijual kembali ke pabrik yang ada di Desa Ban. Di Desa Ban hanya terdapat satu pabrik yang mengolah kacang mete yakni East Bali Cashews.

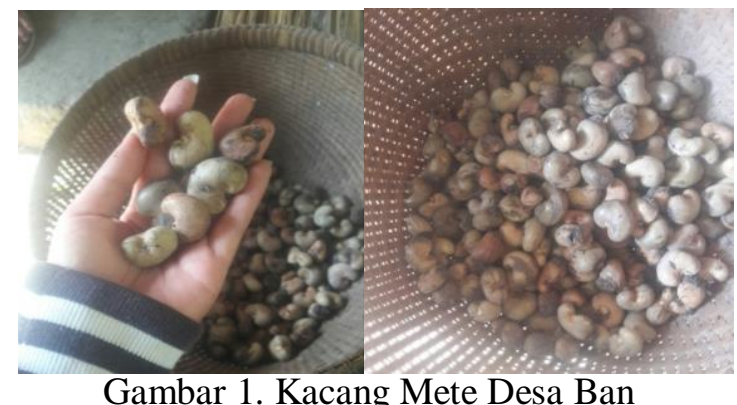

Gambar 1. Kacang Mete Desa Ban

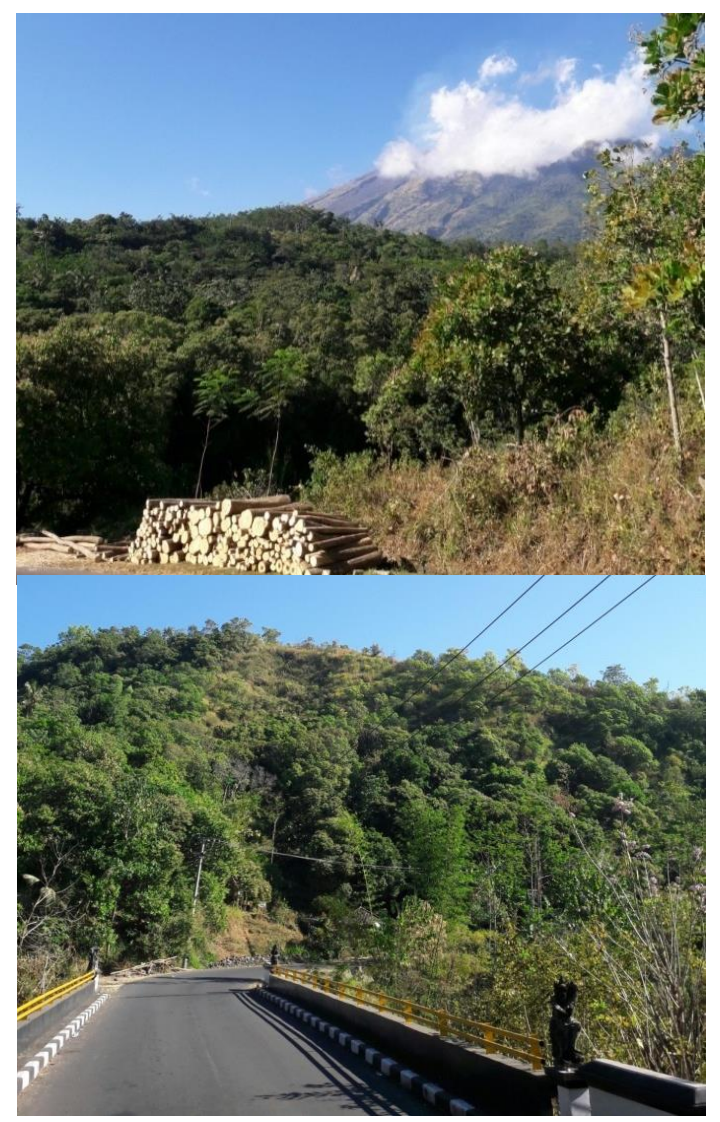

Gambar 2. Perkebunan Kacang Mete Desa Ban

Pabrik East Bali Cashew dimiliki oleh Warga Negara Asing yang bekerja sama dengan beberapa investor lokal. Didirikannya pabrik ini guna memanfaatkan hasil perkebunan mete yang berada di Desa Ban untuk diolah lebih lanjut sehingga memiliki nilai jual yang lebih tinggi. Pabrik East Bali Cashews memberdayakan masyarakat lokal sehingga tersedianya lapangan pekerjaan bagi masyarakat lokal. Sampai saat ini staf yang dipekerjakan di pabrik ini sekitar 350 orang dan hampir $90 \%$ tenaga kerjanya ialah wanita. Pabrik ini 
memiliki kantor pusat untuk kegiatan distribusi dan promosi di daerah Padang Galak Kesiman, Denpasar. Pabrik East Bali Cashews tidak hanya memproduksi olahan mete namun juga mengolah buah kelapa, pisang, ubi cilebu, kolang kaling dan rosela. Kacang mete merupakan komoditas ekspor yang memiliki pangsa pasar yang luas sehingga produk dari East Bali Cashewtidak hanya dijual di negara Indonesia namun sudah diekspor ke beberapa negara di dunia. Pabrik ini juga mendirikan prasekolah bagi anak-anak dari tenaga kerja di pabrik guna meningkatkan pendidikan dan kesejahteraan masyarakat lokal.

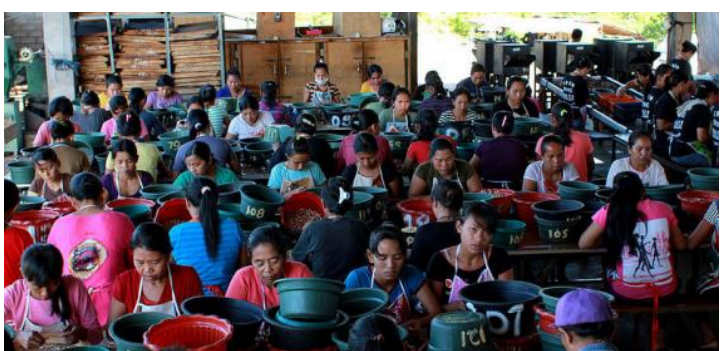

Gambar 3. Tenaga Kerja Lokal di East Bali Cashew

Tidak hanya perkebunan buah mete, Desa Ban juga memiliki varietas tanaman lain yang dapat menjadi potensi desa yakni :

a. Tanaman kopi

Jenis kopi yang terdapat di Desa Ban ialah kopi Arabika. Masyarakat Desa Ban belum memiliki kemampuan dalam pengolahan kopi, padahal hasil dari perkebunan kopi sangat melimpah. Masyarakat menjual bahan baku kopi tanpa diolah.

b. Pohon Siwalan (Lontar)

Pohon Siwalan (Lontar) yang terdapat di Desa Ban tidak sebanyak pohon mete yang ada namun pohon ini memberikan manfaat kepada masyarakat lokal. Air yang didapat dari pohon Siwalan (Lontar) akan diolah oleh masyarakat lokal menjadi gula. Namun juga terdapat air Siwalan (Lontar) yang disebut Tuak oleh masyarakat setempat yang dikirim ke daerah Abang Karangasem untuk dijual ataupun diolah menjadi Arak.

Selain tanaman tersebut di Desa Ban juga terdapat beberapa tanaman lain namun tidak berjumlah banyak seperti Palawija (jagung, ketela pohon, kacangkacangan) dan tanaman holtikultura (mangga, pepaya, pisang) serta terdapat juga pohon kelapa. Pada wilayah Desa Ban tidak hanya berkembang pertanian namun juga peternakan, peternakan yang terdapat di Desa Ban meliputi sapi, kambing, ayam kampung, dan babi.

\section{Kebijakan Pemerintah Daerah dalam Pengembangan Agrowisata di Desa Ban, Kabupaten Karangasem}

Berpedoman pada Undang-Undang Nomor 10 Tahun 2009 tentang Kepariwisataan, Pemerintah Kabupaten Karangasem mengedepankan potensipotensi pariwisata dalam tiga daya tarik wisata yaitu daya tarik wisata alam, daya tarik wisata budaya dan daya tarik wisata buatan. Desentralisasi pembagian urusan pemerintahan dari pusat ke daerah dalam hal ini merupakan desentralisasi bidang otonomi kepariwisataan.

Kewenangan yang dimiliki Kabupaten Karangasem merupakan kewenangan delegasi. Kewenangan delegasi Pemerintah Kabupaten Karangasem tertuang dalam produk hukum berupa Rencana Induk Pembangunan Kepariwisataan Daerah (RIPPARDA) Kabupaten Karangasem. RIPPARDA Kabupaten Karangasem tidak boleh bertentangan dengan Rencana Tata Ruang dan Wilayah Kabupaten Karangasem sehingga kawasan-kawasan lindung, kawasan konservasi, kawasan rentan ataupun kawasan rawan bencana tidak diperuntukkan sebagai kawasan atau daya tarik wisata kecuali mengembangkan pariwisata yang ramah lingkungan dan berkelanjutan seperti agrowisata atau ekowisata.Agrowisata dapat menekan serendah-rendahnya dampak negatif terhadap alam dan kebudayaan yang dapat merusak daerah tujuan wisata (Pitana, 2002). 
Kawasan Rawan Bencana Gunung Api di Kabupaten Karangasem merupakan kawasam rawan letusan gunung berapi yang dapat didefinisikan sebagai kawasan yang rentan, berpotensi tinggi terkena dampak dan mengalami bencana letusan gunung berapi. Kawasan rawan bencana gunung api terbagi menjadi tiga kategori yaitu :

1. Kawasan Rawan Bencana I (KRB I)

Merupakan kawasan di lingkaran terluar dari kawasan rawan bencana, dengan jarak dimulai dari $7 \mathrm{~km}$ dari gunung api. Kawasan ini merupakan kawasan yang diperbolehkan peruntukkannya sebagai daya tarik wisata tetapi dengan adanya syaratsyarat tertentu.

2. Kawasan Rawan Bencana II (KRB II) Kawasan ini berada pada jarak 5-7 km.Merupakan kawasan yang bebas dari pemukiman tetapi dapat dimanfaatkan dengan syarat-syarat tertentu. Syarat-syarat tertentu tersebut antara lain daya tarik wisata berupa atraksi ekologis dengan jenis atraksi yaitu Agro-Kultural, seperti agrowisata, hutan rakyat dan berbagai macam pola agroforestry.

3. Kawasan Rawan Bencana III (KRB III) Merupakan kawasan yang steril dari pemukiman masyarakat dan minim kegiatan masyarakat. Kawasan ini berada pada jarak 1-5 km dari gunung api. Wilayah ini sebagian besar berupa hutan lindung.

Desa Ban masuk ke dalam lingkar kedua Kawasan Rawan Bencana yaitu KRB II dengan tingkat resiko bencana sedang dari kawasan lainnya. Kebijakan pemerintah menjadi kunci utama dalam memilih bentuk daya tarik wisata sebagai identitas Desa Ban. Pemilihan daya tarik wisata harus sesuai dengan kebutuhan masyarakat dan pelestarian alam.

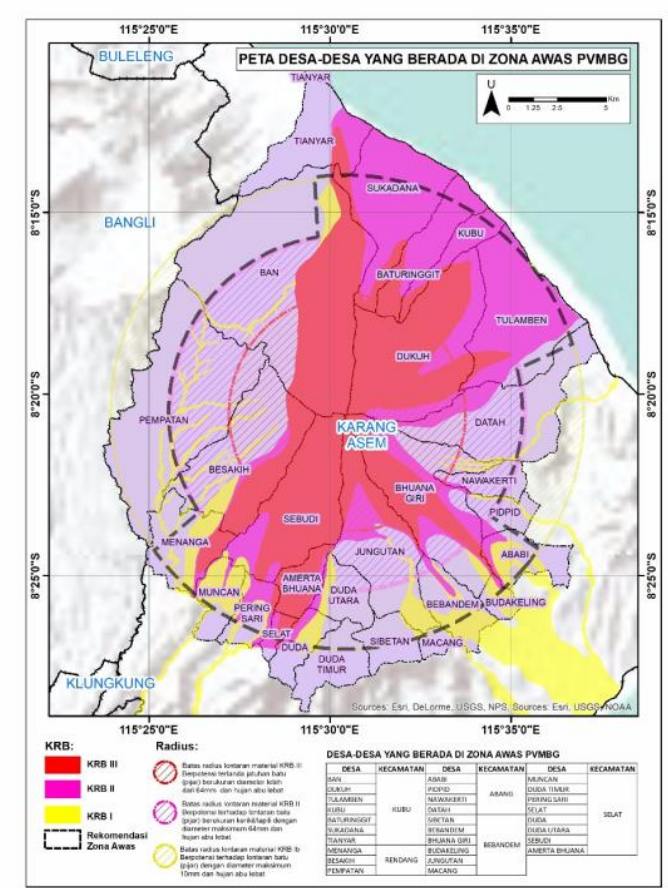

Gambar 4. Peta Kawasan Rawan Bencana Gunung Agung, Kabupaten Karangasem, Provinsi Bali

Tanpa perencanaan yang baik, pariwisata sangat rentan merubah suatu kawasan atau destinasi. Dampak erupsi Gunung Agung perlu menjadi faktor utama dalam menentukan pengembangan pariwisata di Desa Ban. Sesuai dengan arahan Peraturan Menteri Pekerjaan Umum No. 21/PRT/M/2007 tentang Pedoman Penataan Ruang Kawasan Rawan Letusan Gunung Berapi dan Kawasan Rawan Gempa Bumi menyatakan Kawasan Rawan Bencana Gunung Api maka daya tarik wisata buatan berupa agrowisata menjadi pilihan dalam pengembangan pariwisata di Desa Ban.

Potensi kuat Desa Ban dalam perkebunan menjadikan daya tarik wisata buatan menjadi pilihan utama. Nilai pembeda terhadap potensi perkebunan Desa Ban yang tidak dimiliki desa lain di Kabupaten Karangasem akan membuat Desa Ban diminati. Kawasan Rawan Bencana II dapat dimanfaatkan sebagai daya tarik wisata tetapi dengan durasi operasional selama 8 jam. Agrowisata 
tidak memerlukan kegiatan menginap atau kegiatan yang memerlukan waktu 24 jam operasional seperti usaha penyediaan akomodasi. Durasi operasional agrowisata kacang mete beroperasi pada 8 jam operasinal kerja masyarakat Indonesia pada umumnya. Dimulai 08.00 pagi sampai 16.00 sore atau jam 09.00 pagi sampai 17.00 sore. Disarankan juga untuk bangunan agrowisata diselaraskan dengan bangunan yang ramah lingkungan (semi permanen) seperti bangunan yang terbuat dari bambu.Apabila terjadi erupsi gunung api maka evakuasi akan lebih mudah. Dampak erupsi pada perkebunan jauh lebih rendah kerugiannya dibandingkan dengan pengembangan pariwisata dengan jenis usaha pariwisata lainnya seperti usaha penyediaan makanan dan minuman atau usaha penyediaan akomodasi.

Agrowisata kacang mete di Desa Ban menjadi agrowisata yang berbasis industri. Industri yang dimaksud adalah masyarakat lokal dapat menanam varietas tanaman lainnya disamping keunggulan varietas tanaman lokal, mengikuti keperluan atau kebutuhan bahan baku dari produk East Bali Cashews. Beragamnnya varietas tanaman yang dikembangkan akan memperkaya agrowisata. Wilayahwilayah yang masih kosong dapat ditanami untuk memperluas area agrowisata untuk kegiatan wisatawan. Wisatawan dapat melakukan trekking di kebun masyarakat, dipandu dengan masyarakat lokal sembari memberikan edukasi varietas tamanan lokal baik fungsi maupun manfaatnya. Wisatawan dapat dibuatkan kegiatan lain seperti pengolahan kacang mete dan hasil perkebunan lainnya. Masyarakat juga dapat menjual produk olahan rumah (home made) dari olahan-olahan kacang mete kepada wisatawan dengan kemasan yang unik (tradisional higienis).

Masyarakat lokal belum paham akan peruntukan ganda suatu kawasan, seperti kawasan perkebunan mete dapat difungsikan sebagai agrowisata. Masyarakat lokal tetap dapat memanen kacang mete tetapi perkebunan mereka juga dapat dikunjungi wisatawan.
Pengajaran atau edukasi pengolahan mete akan memberikan manfaat lebih pada masyarakat yang menjual produk olahan kacang mete di agrowisata kacang mete. Masyarakat lokal tetap dapat mengirimkan hasil perkebunan mereka kepada pengepul dan juga dapat mengolah hasil perkebunan untuk mendapat nilai ekonomi lebih.

Agrowisata lebih bersahabat dengan masyarakat lokal dan mampu dikembangkan oleh masyarakat lokal Melihat sistem kelembagaan masyarakat dalam perkebunan di Desa Ban, perkebunan kacang mete diakomodir oleh Kelompok Tani.Desa Ban memiliki 15 Banjar dan masing-masing banjar miliki kelompok tani. Pengembangan agrowisata akan lebih mudah karena sudah ada kelembagaan masyarakat lokal yang mengatur perkebunan. Pemerintah Daerah akan lebih mudah melakukan promosi Desa Ban sebagai salah satu desa penghasil kacang mete kualitas super dengan standar internasional. Diharapkan masyarakat tidak hanya sebagai penonton saja dalam pembagian kue pariwisata, masyarakat juga mendapatkan manfaat dari pariwisata.

\section{KESIMPULAN}

Desa Ban termasuk dalam KRB II Gunung Agung dengan jarak 5-7 km dari Gunung Agung. Kebijakan Pemerintah Daerah Kabupaten Karangasem dalam pengembangan pariwisata diperbolehkan pada KRB II dengan syarat tertentu yaitu daya tarik wisata berupa atraksi ekologis dengan jenis atraksi yaitu Agro-Kultural, seperti agrowisata, hutan rakyat dan berbagai macam pola agroforestry. Pengembangan agrowisata kacang mete dinilai ideal dengan durasi operasional selama 8 jam (08.00 pagi sampai 16.00 sore atau jam 09.00 pagi sampai 17.00 sore). Bangunan agrowisata bersifat semi permanen, berasal dari bahan bangunan yang ramah lingkungan seperti bangunan bambu. Agrowisata berbasis industri tidak terkesan eksploitatif tetapi lebih pada bagaimana petani lokal dengan pola tradisional dapat memenuhi supply bahan baku sebuah industri. Citra postif 
pariwisata berkelanjutan (green tourism)dapat terbangun melalui kearifan lokal masyarakat yang membudidayakan varietas tanaman dengan pola tradisional.

\section{DAFTAR PUSTAKA}

Marbun, SF. (1997). Peradilan Administrasi Negara dan Upaya Administratif di Indonesia, Liberty, Yogyakarta.

Winarno, Budi. (2002). Kebijakan Publik: Teori dan Proses. Media Presindo, Yogyakarta.

ESCAP , United Nation. (2015). Disaster in Asia and The Pasific 2015 Year in Review. Economi and Social Commission for Asia and the Pasific, Thailand.

Pitana, I Gede. (2002). Kebijakan dan Strategi Pemerintah Daerah Bali dalam Pembangunan Pariwisata. Pada Seminar Nasional Pariwisata Bali the Last or the Lost Paradise. Pembangunan Pariwisata yang Berkelanjutan.Denpasar: Universitas Udayana.

\section{Perundang-Undangan}

Undang-Undang No. 10 Tahun 2009 tentang Kepariwisataan (Lembaran Negara Republik Indonesia Tahun 2009 Nomor 11).

Peraturan Menteri Pekerjaan Umum No. 21/PRT/M/2007 tentang Pedoman Pentaan Ruang Kawasan Rawan Letusan Gunung Berapi dan Kawasan rawan Gempa Bumi. 